\title{
Rayleigh LIDAR and satellite (HALOE, SABER, CHAMP and COSMIC) measurements of stratosphere-mesosphere temperature over a southern sub-tropical site, Reunion $\left(20.8^{\circ} \mathrm{S} ; \mathbf{5 5 . 5}^{\circ} \mathrm{E}\right)$ : climatology and comparison study
}

\author{
V. Sivakumar ${ }^{1,2,3,4}$, P. Vishnu Prasanth ${ }^{1,5}$, P. Kishore $^{6}$, H. Bencherif ${ }^{1}$, and P. Keckhut ${ }^{7}$ \\ ${ }^{1}$ Laboratoire de l'Atmosphère et des Cyclones (LACy), UMR 8105, INSU/CNRS, Université de La Reunion, Reunion Island, \\ France \\ ${ }^{2}$ National Laser Centre (NLC), Council for Scientific and Industrial Research (CSIR), P.O. Box 395, Pretoria 0001, \\ South Africa \\ ${ }^{3}$ Department of Geography, Geoinformatics and Meteorology, University of Pretoria, Lynwood Road, Pretoria 0002, \\ South Africa \\ ${ }^{4}$ School of Physics, University of KwaZulu Natal, Durban 4000, South Africa \\ ${ }^{5}$ Sree Vidyanikethan Engineering College, Sree Sainath nagar, Tirupathi - 517 102, Andhra Pradesh, India \\ ${ }^{6}$ Department of Earth System Science, University of California, Irvine, CA 92697, USA \\ ${ }^{7}$ Laboratoire Atmosphères Milieux Observations Spatiales (LATMOS), IPSL (UMR 8190), 11, Boulevard d'Alember, 78280, \\ Guyancourt, France
}

Received: 7 January 2011 - Revised: 31 March 2011 - Accepted: 1 April 2011 - Published: 12 April 2011

\begin{abstract}
For the first time, climatology of the middle atmosphere thermal structure is presented, based on 14 years of LIDAR and satellite (HALOE, SABER, CHAMP and COSMIC) temperature measurements. The data is collected over a southern sub-tropical site, Reunion Island $\left(20.8^{\circ} \mathrm{S}\right.$; $55.5^{\circ} \mathrm{E}$ ), for the height range between 30 and $60 \mathrm{~km}$. The overall monthly mean temperature shows a maximum of $265-270 \mathrm{~K}$ at the stratopause height region from $\sim 44-52 \mathrm{~km}$ and peaks during the months of March and November. Furthermore, the temperature profiles are compared with different satellite datasets (HALOE, CHAMP, COSMIC and SABER) and the results are found to be in reasonable agreement with each other, although a relative difference in temperature of \pm 5 to $6 \mathrm{~K}$ is noticed. In comparison, LIDAR shows higher/lower temperatures for the lower mesosphere/upper stratosphere height region. The differences in temperature measured by the LIDAR and satellite measurements are analogous with previous results available elsewhere. Long-term temperature measurements are used to further study seasonal oscillations, especially annual, semi-
\end{abstract}

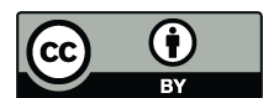

Correspondence to: V. Sivakumar (svsk74@gmail.com) annual and quasi-biennial oscillations. In comparison with $\mathrm{SAO}$, the measured spectral amplitudes of AO shows dominant amplitudes in both the upper stratosphere and lower mesosphere height regions. Using LIDAR and the other satellite measurements, the quasi-biennial oscillation was found to be approximately 26 months. The spectral amplitudes are comparable to the results reported earlier by other researchers.

Keywords. Atmospheric composition and structure (Middle atmosphere - composition and chemistry; Pressure, density, and temperature; Instruments and techniques)

\section{Introduction}

The growing interest in understanding global climate change extends into the middle and upper atmosphere. While greenhouse gases, such as $\mathrm{CO}_{2}$ and $\mathrm{CH}_{4}$ heat the lower atmosphere by absorbing infrared radiation, they are also efficient radiators of heat resulting in cooling the middle and upper atmosphere (Roble and Dickinson, 1989). Doubling the $\mathrm{CO}_{2}$ concentration is predicted to cool the stratopause $(\sim 50 \mathrm{~km})$ by 10 to $12 \mathrm{~K}$ and the mesopause region $(\sim 80$ to

Published by Copernicus Publications on behalf of the European Geosciences Union. 
$100 \mathrm{~km}$ ) by 6 to $12 \mathrm{~K}$ (Portman et al., 1995). Modeling the middle atmosphere is hampered by the lack of observational data and the uncertainties in the parameterization of gravity waves. Observational studies of the middle and upper atmosphere, which underlie our understanding of the global climate change, provide crucial tests of atmospheric general circulation models. Such studies lead to improvements in the models and our knowledge of the global atmosphere (Randel et al., 2004).

Optical and radio remote sensing instruments and in-situ rocket measurements are the most common sources of observational data for the middle atmosphere height regions. Among them, LIDAR (Light Detection and Ranging) techniques are unique in their capabilities of providing high spatial and temporal resolution measurements of temperature, wind and constituent structure in the middle atmosphere region. It is a well established fact that the Rayleigh LIDAR provides middle atmospheric temperature profiles from upper stratosphere to mesosphere $(30-80 \mathrm{~km})$ with a high resolution in comparison with other instruments, such as rocketsondes, falling sphere and satellites etc. Satellite observations provide the global picture of temperature structures but limited by temporal variation at a particular place and the limited time and height resolution. LIDAR measurements provide an economical solution for continuously observing short term changes in temperature over long periods of time and at a particular place. Such LIDAR temperature measurements are compared and validated by other measurements and space-borne experiments such as, Microwave Limb Sounder (MLS), Halogen Occultation Experiment (HALOE) onboard Upper Atmosphere Research Satellite (UARS), GPS, COSMIC, SABER etc., (Fishbein et al., 1996; Gille et al., 1996; Hervig et al., 1996; Remsberg et al., 2002a, b).

Over the last two decades, the middle atmospheric temperature climatology has been studied by various researchers around the world (e.g., Hauchecorne et al., 1991; Clancy et al., 1994; Leblanc et al., 1998a, b; Sivakumar et al., 2003; Randel et al., 2004; Li et al., 2008). Randel et al. (2004) made a detailed study of the middle atmosphere temperature climatology based on different instruments including LIDAR. They have also compared the temperature measurements with other instruments. However, the study lacks in terms of LIDAR observations over the Southern Hemisphere, especially over the tropics. Recently, Dou et al. (2009) studied the seasonal oscillations of middle atmosphere temperature, measured by six different Rayleigh LIDARs located over the low- to high-latitudes. They noted a strong Annual Oscillation (AO) both in the stratosphere and in the mesosphere over mid- and high-latitude regions.

Although Rayleigh LIDAR systems provide temperature measurements at different locations around the globe, most of them are located in the Northern Hemisphere (e.g., Hauchecorne et al., 1991; Whiteway and Carswell, 1994; Leblanc et al., 1998a, b; Sivakumar et al., 2003; Randel et al., 2004; Li et al., 2008). Over the southern tropics, middle atmosphere temperature measurements are very limited (Bencherif et al., 1996, 2000; Morel et al., 2002; Moorgawa et al., 2007; Batista et al., 2008, 2009). Over Reunion Island $\left(20.8^{\circ} \mathrm{S} ; 55.5^{\circ} \mathrm{E}\right)$, a Rayleigh LIDAR system has been operating since 1994. The LIDAR system has been providing quasi-continuously temperature profiles from 30 to $80 \mathrm{~km}$. A few research studies based on the Reunion Rayleigh LIDAR temperature measurements have been reported but they are limited to case studies (Morel et al., 2002; Raju et al., 2010). Morel et al. (2002) studied the tidal perturbations in the temperature profiles obtained from the Reunion Rayleigh LIDAR, based on a limited dataset (2-3 weeks during November 1995). Apart from the above studies, neither a detailed temperature climatological study nor a systematic comparison of the LIDAR measurements with other insitu-satellite data has been made. In this paper, we use data collected over a long period, i.e. $\sim 14$ years of LIDAR observations for the period from 1994 to 2007, to investigate the temperature climatology. We make a comparison with different satellite measurements (including HALOE, CHAMP, COSMIC and SABER) and also illustrate the annual, semi-annual and quasi-biennial oscillations.

\section{System and data}

\subsection{Rayleigh LIDAR system at Reunion Island}

A Rayleigh LIDAR system was implemented by the Laboratoire de l'Atmosphère et des Cyclones (LACy) located in the north of Reunion Island $\left(20.8^{\circ} \mathrm{S} ; 55.5^{\circ} \mathrm{E}\right)$, which is a subtropical site. It has been in operation since 1994. Basically, the system transmits the second harmonic of the Nd:YAG laser $(532 \mathrm{~nm})$ vertically through the atmosphere. The laser is operated at $30 \mathrm{~Hz}$ and characterized by $10 \mathrm{~ns}$ pulses with pulse energy of $300 \mathrm{~mJ}$ (Bencherif et al., 1996). The backscattered photons are collected by a telescope made of 4 different primary mirrors having a total surface area of $\sim 0.67 \mathrm{~m}^{2}$. By assuming that the atmosphere is in hydrostatic equilibrium and free from aerosols (above $30 \mathrm{~km}$ ), the vertical temperature profiles are computed. For temperature retrieval, we use the COSPAR International Reference Atmosphere (CIRA-86) standard model of the atmosphere for the reference pressure values at the top of the atmosphere $(\sim 80 \mathrm{~km})$ as explained by Hauchecorne and Chanin (1980). In general, the uncertainty in temperature retrieval by Rayleigh LIDAR, due to the assumed value of pressure at the top of profile, decreases rapidly within $10-15 \mathrm{~km}$ below the reference height and is less than 1\% (Sivakumar et al., 2003).

The Reunion Rayleigh LIDAR system has been used for retrieving temperature since 1994 and the measurements are made with in the framework of the Network for the Detection of Atmospheric Composition Change (NDACC) (Keckhut et 
al., 2004). For homogeneity and in order to reduce error and bias on temperature fluctuations due to a low signal-to-noise ratio in the upper heights, the LIDAR profiles are limited to the altitude range from 30 to $60 \mathrm{~km}$ even though the temperatures were derived up to $80 \mathrm{~km}$. The raw LIDAR data is collected as photon count profiles with a height resolution of $300 \mathrm{~m}$ and a time resolution of $122 \mathrm{~s}$. In the present study, we make use of 14 years (1994-2007) of Rayleigh LIDAR observations, which corresponds to approximately 1534 night time measurements. LIDAR observations are made quasicontinuously and are averaged over three to six hours within the time interval of 20:00 h-04:00 h (Local Time). We have used the night time averaged profiles which correspond to at least $2 \mathrm{~h}$ of measurement, thereby providing a good signal to noise ratio (SNR) and better accuracy. In total, we have used 665 temperature profiles for the present study. On average, we have found about 60 temperature profiles per month which would be useful for good climatological studies. It should be noted that the LIDAR observations are restricted to cloud free nights.

\subsection{HALOE}

HALOE was launched on the UARS spacecraft as a part of the Earth Science Enterprise (ESE) program, on 12 September 1991. Basically, the solar occultation technique is used to measure vertical profiles of a number of minor constituents, aerosol concentrations and temperature profiles. The height resolution of the measurements is $3.7 \mathrm{~km}$ for an instantaneous field of view of $1.6 \mathrm{~km}$ at the earth's limb. By making use of atmospheric transmission, the temperature profiles are retrieved by removing the aerosol contribution above $30 \mathrm{~km}$. Remsberg et al. (2002b) made a detailed comparison of HALOE temperature measurements with LIDAR and inflatable falling sphere measurements and good agreement was found between them. More details about the quality of HALOE data can be found in the published literature (e.g., Russell et al., 1993; Randel et al., 1998; Remsberg et al., 2002a, b). We have used 11 years (1994-2004) of HALOE satellite overpasses to the LIDAR site, Reunion $\left(20.8^{\circ} \mathrm{S}\right.$, $55.5^{\circ} \mathrm{E}$ ), with $\pm 3^{\circ}$ in latitudinal and $\pm 15^{\circ}$ in longitudinal discrepancies. The data includes both sunrise and sunset events of 217 individual profiles.

\subsection{CHAMP and COSMIC}

The availability of GPS radio signals has introduced a new and promising remote sensing technique for the Earth's atmosphere (e.g. Melbourne et al., 1994; Kursinski et al., 1997; Anthes et al., 2000; Steiner et al., 2000). The use of active radio signals enables measurements during the day and night. The uses of L-band signals, with wavelengths of $\sim 20 \mathrm{~cm}$, ensure that the signals are negligibly influenced by aerosols and clouds. A potential for long term surveillance of temperature with high spatial resolution and accuracy is offered by
GPS Radio Occultation (RO) measurements. The successful application of the GPS Radio occultation mission represents a revolution in atmospheric soundings from space, with accurate and all-weather global observations, climate and space weather research and operations (Kursinski et al., 1997; Wickert et al., 2001; Hajj et al., 2002; Anthes et al., 2008). The German CHAMP (Challenging Minisatellite Payload) satellite was launched on July 2000, with an initial altitude of about $454 \mathrm{~km}$. CHAMP provided 150-200 sounding per day and was used in a circular and near polar orbit, with an inclination of $87.2^{\circ}$.

Constellation Observation System for Meteorology Ionosphere and Climate (COSMIC)/Formosa Satellite-3 (FORMOSAT-3) was launched in April 2006, under a joint Taiwan-USA collaboration. COSMIC is providing 1500-1600 soundings per day within the height interval 0-60 km. A distinctive feature of the COSMIC mission, compared to previous missions, is the employed open loop (OL) mode where the RO mission is tracked during both set and rise neutral atmospheric occultation in the lower troposphere (Schreiner et al., 2007). The open-loop tracking technique will significantly reduce the GPS RO inversion biases by eliminating tracking errors (Sokolovskiy et al., 2007). The present study considers CHAMP data from the Reunion site overpass during the period from January 2002 to December 2007 and COSMIC data from July 2006 to February 2008. We have used both COSMIC and CHAMP satellite data corresponding to overpasses to the LIDAR site, $\left(20.8^{\circ} \mathrm{S}, 55.5^{\circ} \mathrm{E}\right)$, with $\pm 2^{\circ}$ and $\pm 10^{\circ}$ in latitudinal and longitudinal discrepancies, respectively.

\subsection{SABER}

In addition to the LIDAR and COSMIC datasets, we have also utilized temperature data obtained from the Sounding of the Atmosphere using the Broadband Emission Radiometry (SABER) instrument on the Thermosphere-IonosphereMesosphere Energetics and Dynamics (TIMED) satellite, which was launched on 7 December 2001. It provides temperature profiles from the lower stratosphere to the lower thermosphere, with a vertical resolution of $\sim 2 \mathrm{~km}$. The SABER temperature profiles are downloaded from the website: http://saber.gats-inc.com. More recently, Dou et al. (2009) used the SABER temperature data and found good agreement when compared with LIDAR measurements. More details about the SABER temperature data quality and its validation can be found in the published literature (for e.g. Remsberg, 2003). We have used 6 years (2002-2007) of SABER satellite overpasses to the LIDAR site, Reunion $\left(20.8^{\circ} \mathrm{S}, 55.5^{\circ} \mathrm{E}\right)$, with $\pm 2^{\circ}$ and $\pm 10^{\circ}$ in latitudinal and longitudinal discrepancies. 


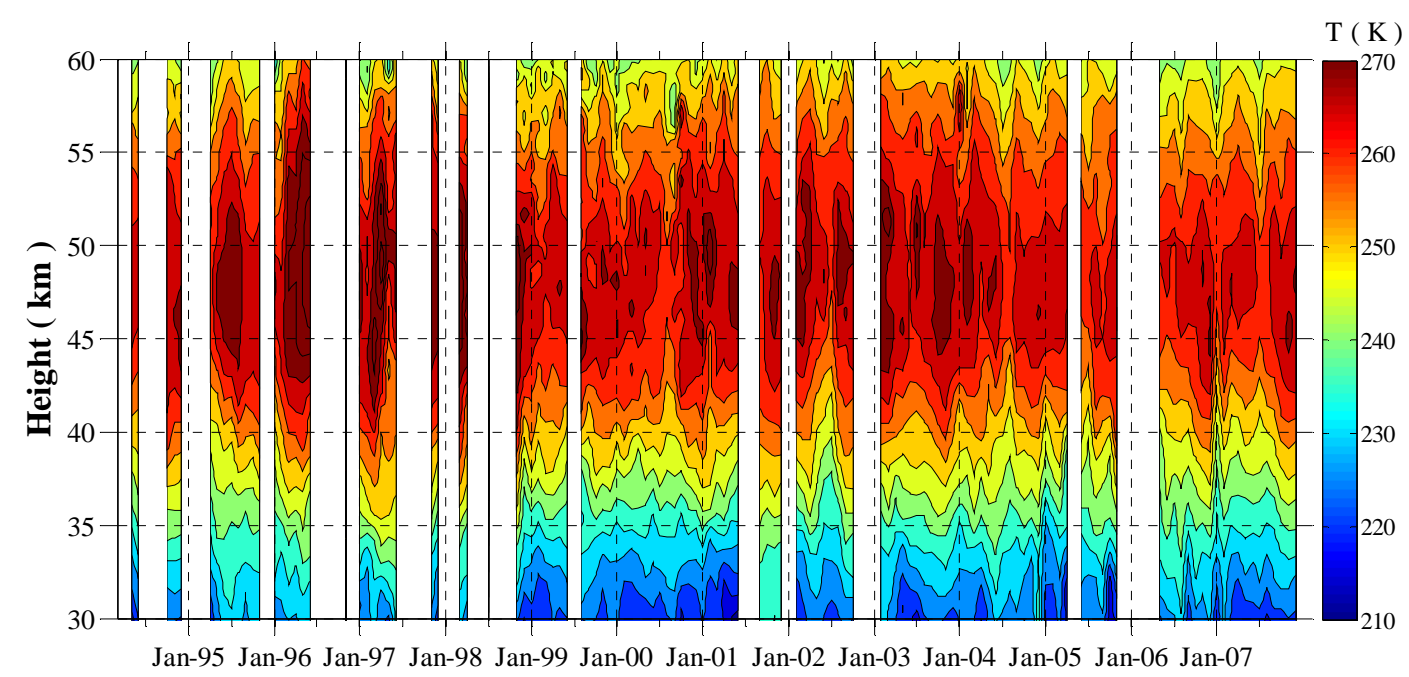

Month ( January-1994 to December-2007 )

Fig. 1. Temporal evolution of monthly mean temperature obtained from LIDAR observations over Reunion Island for the period from January 1994 to December 2007. The blank spaces in the figure illustrate times during which no data was collected.
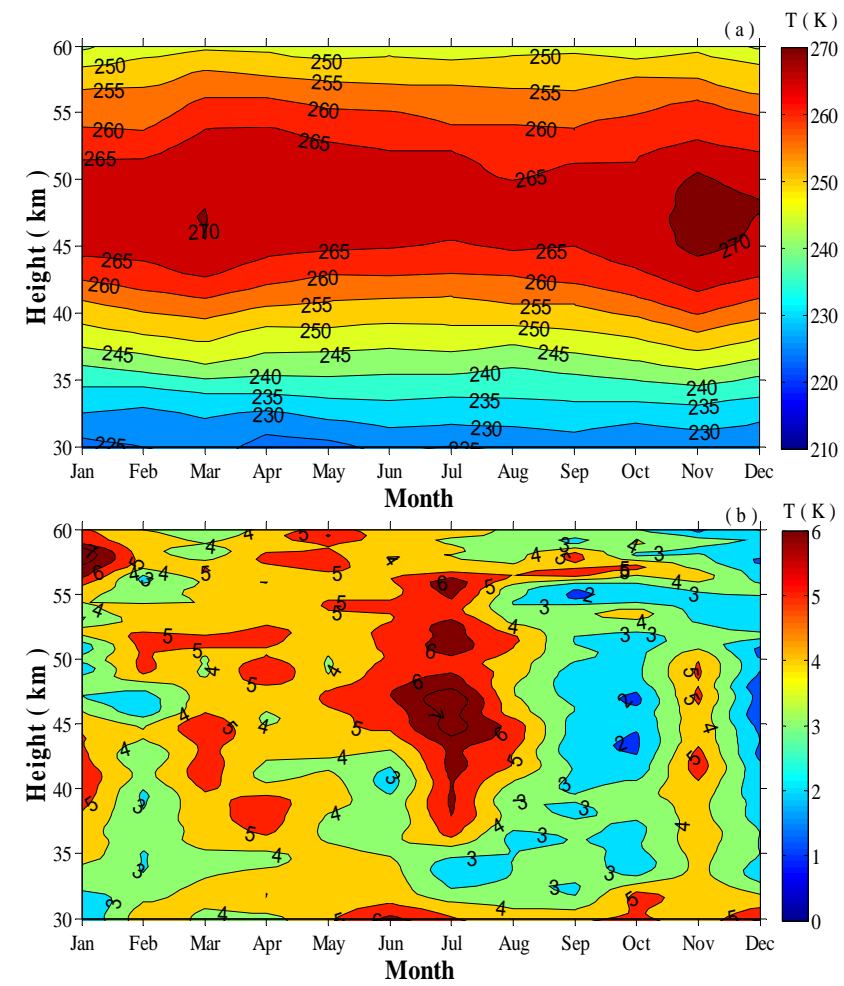

Fig. 2. Contour plot of (a) monthly mean temperature and (b) standard deviation obtained from the LIDAR over the period from 1994 to 2007 .

\section{Results and discussion}

\subsection{Climatological characteristics by LIDAR measurements}

Figure 1 shows the temporal evolution of temperature obtained by LIDAR for the height range from $30 \mathrm{~km}$ to $60 \mathrm{~km}$. The figure illustrates the variation of temperature for the height range and illustrates the systematic oscillations over years. The blank areas in the figure represent the data gaps when no observations were made, due to background atmosphere conditions or technical problems. Apart from the expected increase in temperature up to stratopause altitudes and a decrease at higher altitudes, the figure addresses systematic changes in the temperature and allows us to study different kinds of oscillations, such as annual, semi-annual and quasi biennial oscillations, which are discussed in the later section. It is clear from the figure that the maximum temperature ranges from $260 \mathrm{~K}$ to $270 \mathrm{~K}$ in the stratopause height region from $42 \mathrm{~km}$ to $57 \mathrm{~km}$. This range of stratopause height is found to vary and broaden by December and get thinner during the beginning of the year. A more detailed discussion of stratopause heights and its temperature including their monthly variations is discussed in the following section. During a few years, high temperatures (i.e., greater than $270 \mathrm{~K}$ ) are recorded in the stratosphere which might be due to the occurrence of major or minor sudden stratospheric warming over Southern Hemisphere regions (Bencherif et al., 2007; Mbatha et al., 2010). Further, the monthly means and the corresponding standard deviations are extracted based on the present data. The monthly and seasonal mean temperature profiles are compared with different satellite measurements and discussed in the following sections. 

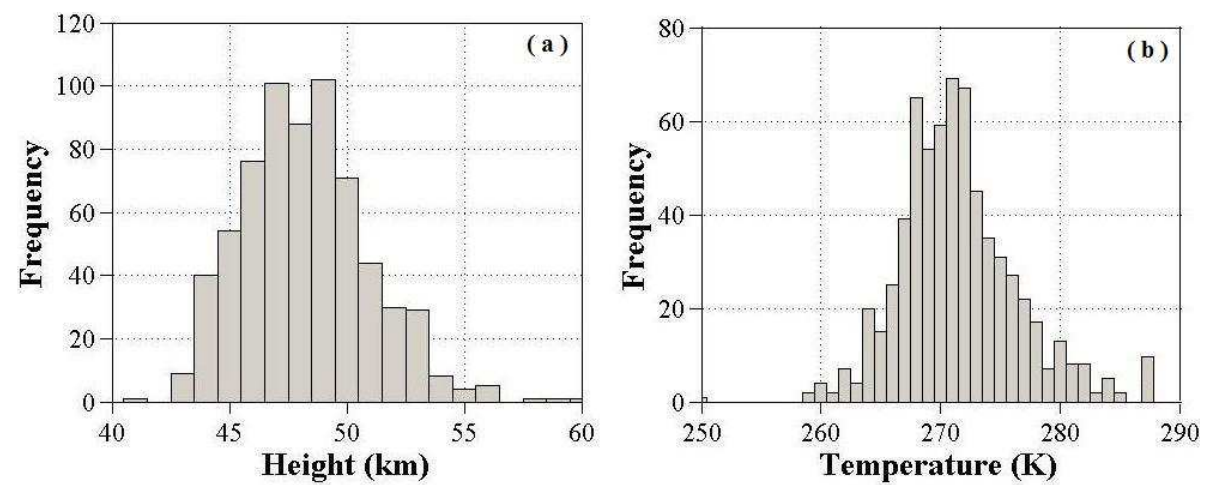

Fig. 3. Histograms showing frequency distribution of (a) stratopause heights and (b) stratopause temperatures.

The climatological monthly mean temperatures are obtained by grouping the LIDAR data in terms of month and irrespective of the year. Hence, the data has better accuracy and the monthly mean profiles are away from the unusual spectacular events (like, stratopause/stratosphere warming, gravity/planetary wave breaking and measurement error). Figure 2a shows the monthly mean variations of temperature obtained for the $30-60 \mathrm{~km}$ height region. In general, the temperatures are found to be fairly stable over months. The stratopause temperature shows distinct maxima during the periods; March-April and October-November. It shows an opposite trend with maximum/minimum temperature oscillations at the lower/upper regions of the stratopause. The stratopause temperature $\sim 260 \mathrm{~K}-270 \mathrm{~K}$ delineates a narrow thickness (3-4 km) during August and extends to a broader thickness $(7-8 \mathrm{~km})$ in the November and March months. The above finding is in good agreement with the results reported from Brazil $\left(23.2^{\circ} \mathrm{S} ; 45.8^{\circ} \mathrm{W}\right)$ by Batista et al. (2009). The figure demonstrates a predominant semi-annual oscillation between 30 and $60 \mathrm{~km}$. This kind of oscillation agrees well with the Northern Hemisphere low latitude observations over Gadanki $\left(13.5^{\circ} \mathrm{N}\right)$ (Sivakumar et al., 2003), while the midlatitude and high latitude observations show a strong annual oscillation (AO) with a maximum during April to July (Chanin and Hauchecorne, 1991; Hauchecorne et al., 1991; Gobbi et al., 1995; Gerding et al., 2008; Schöch et al., 2008). Leblanc et al. (1998b) showed a SAO with maximum temperature of $265 \mathrm{~K}$ at the equinoxes in March/April and September/October at $19.5^{\circ} \mathrm{N}$.

Figure $2 \mathrm{~b}$ shows a contour plot of the standard deviations corresponding to the monthly mean temperature presented in Fig. 2a. The standard deviations are in most cases less than $6 \mathrm{~K}$ in the height range of $30-60 \mathrm{~km}$. While there is no systematic seasonal dependence, the lowest values $(<2 \mathrm{~K})$ occur at heights below $60 \mathrm{~km}$ and during the period from July to October. High values of standard deviations (around 4-6 K) are found during July and more moderate values in earlier months (MAM) for the height range of $35-55 \mathrm{~km}$, around the stratopause region. The highest values which occurred during the austral winter might be associated with seasonal variability due to planetary wave propagation in the winter middle atmosphere. In fact, the winter stratosphere is disrupted by wave activity, chiefly by gravity and planetary waves (Rauthe et al., 2008). These atmospheric waves are mostly generated in the troposphere and in winter they propagate with westerly winds through the middle atmosphere.

Figure 3 a shows the histogram of the observed stratopause height. It is detected at the height where the maximum temperature is noticed. It is apparent from the figure that the stratopause height has a wide distribution ranging from 40 to $60 \mathrm{~km}$ with the maximum frequency of occurrence in the height range of $47-49 \mathrm{~km}$. The distribution is found to be Gaussian shaped with half-width maximum ranging from $45 \mathrm{~km}$ to $51 \mathrm{~km}$. Some cases show high stratopause heights above $54 \mathrm{~km}$, which might be due to the existence of double stratopauses (Sivakumar et al., 2006). In the present study, we have identified the stratopause as the height at which maximum temperature is found, regardless of the double stratopause. On the other hand, the existence of low stratopause heights might be related to the occurrence of stratospheric warming which decreases the stratopause height as the temperature increases by an order of magnitude ( $\sim 10 \mathrm{~K}$ to $20 \mathrm{~K}$ ) (Sivakumar et al., 2004; Bencherif et al., 2007). A histogram in Fig. 3 b shows the distribution of corresponding temperatures at stratopause heights. It roughly illustrates a Gaussian structure with the half-width maximum magnitude ranging from $268 \mathrm{~K}$ to $272 \mathrm{~K}$. The observed stratopause height and temperature distributions are found to be in agreement with other published results (Leblanc et al., 1998a, b; Randel et al., 2004; Batista et al., 2009).

The monthly climatological variations of the mean stratopause temperature and its height are shown along with their corresponding standard deviations in Fig. $4 a$ and b, respectively. The stratopause temperature variation shows a semi-annual cycle with higher values ( $\sim 272 \mathrm{~K}$ to $273 \mathrm{~K})$ during March and November months. The variations in the stratopause height (Fig. 4b) are less clear except for the high value found during July where the mean height is $\sim 49 \mathrm{~km}$. 

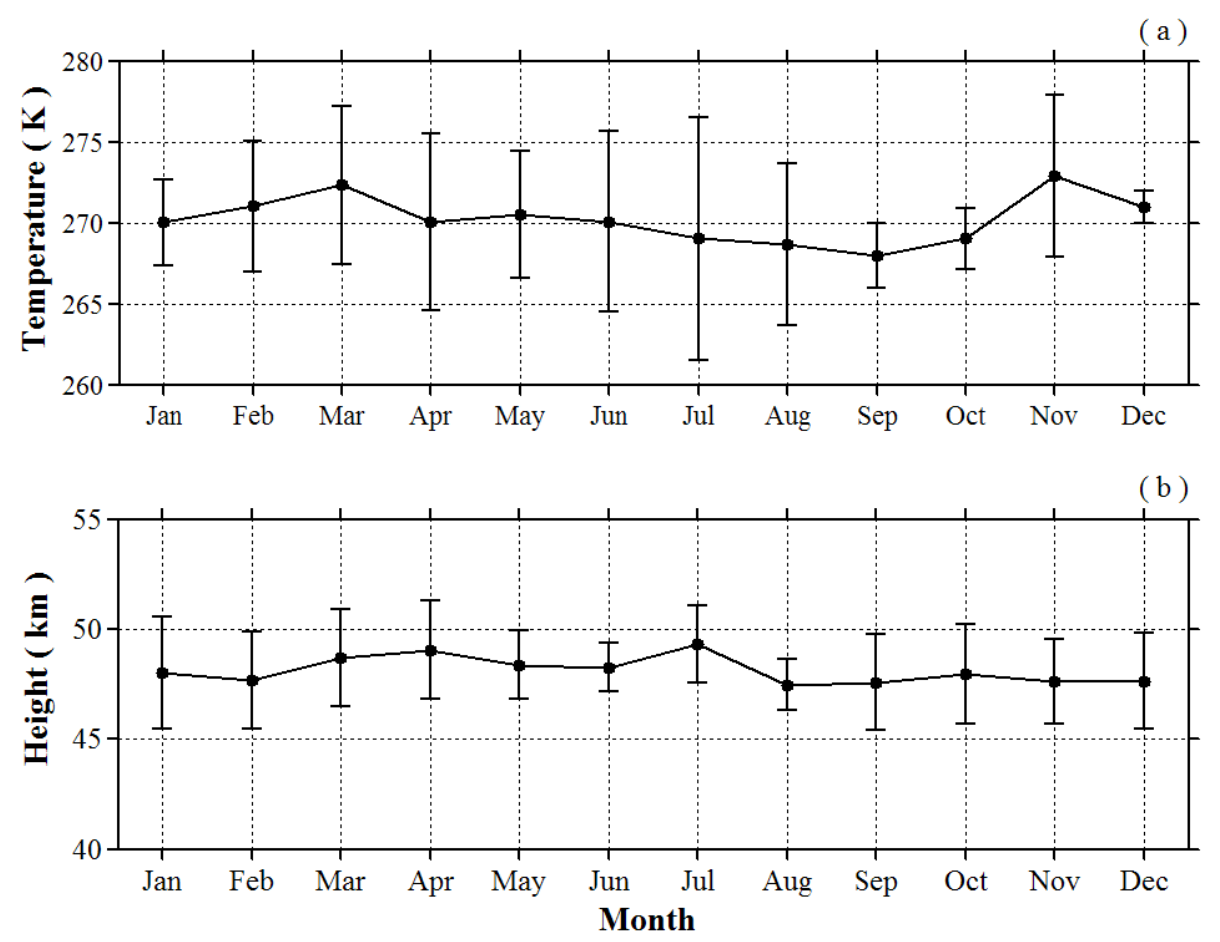

Fig. 4. Monthly climatological variations of (a) temperature and (b) height of stratopause over Reunion Island, with corresponding standard deviations obtained from LIDAR for the period from 1994 to 2007.

\section{9-10 November 1995}

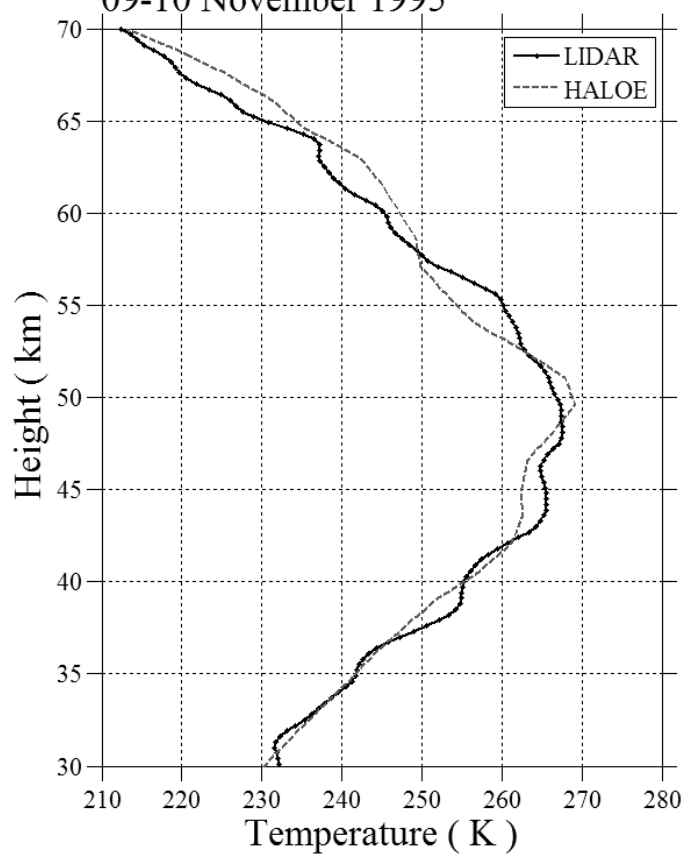

Fig. 5. Quasi-simultaneous height profiles of the temperature observed by the LIDAR and the HALOE satellite for the night of 9-10 November 1995 over Reunion Island.
The stratopause height is found to be stable during the austral summer (DJF) at $\sim 47-48 \mathrm{~km}$ with the temperature varying from $270 \mathrm{~K}$ to $273 \mathrm{~K}$, followed by autumn (MAM) with a moderate variation. During winter (JJA), the stratopause height is found to vary with high values during July with mean temperatures around $269 \mathrm{~K}$. The lowest stratopause temperature of $\sim 268 \mathrm{~K}$ is obtained during September. The observed seasonal characteristics of stratopause are found to be consistent with the recent results reported over Brazil (Batista et al., 2009).

\subsection{Comparison between LIDAR and HALOE satellite data}

In this section, we compare the LIDAR temperature profiles with the HALOE satellite measurements. An example of a comparison between the temperatures measured by HALOE and the LIDAR on the night of 9-10 November 1995 is shown in Fig. 5. The HALOE profile presented here corresponds to the sunset observation (16:57:55 local time; LT) and a near overpass of the LIDAR site $\left(23.6^{\circ} \mathrm{S} ; 63.94^{\circ} \mathrm{E}\right)$. The presented LIDAR profiles are averaged over the night time observations for time period from 20:01:53 LT (9 November 1995) to 03:53:33 LT (10 November 1995). The figure illustrates that temperature measurements obtained by LIDAR and by HALOE are in good agreement with each other. In addition, the LIDAR profiles show the disturbance in temperature due to propagating 

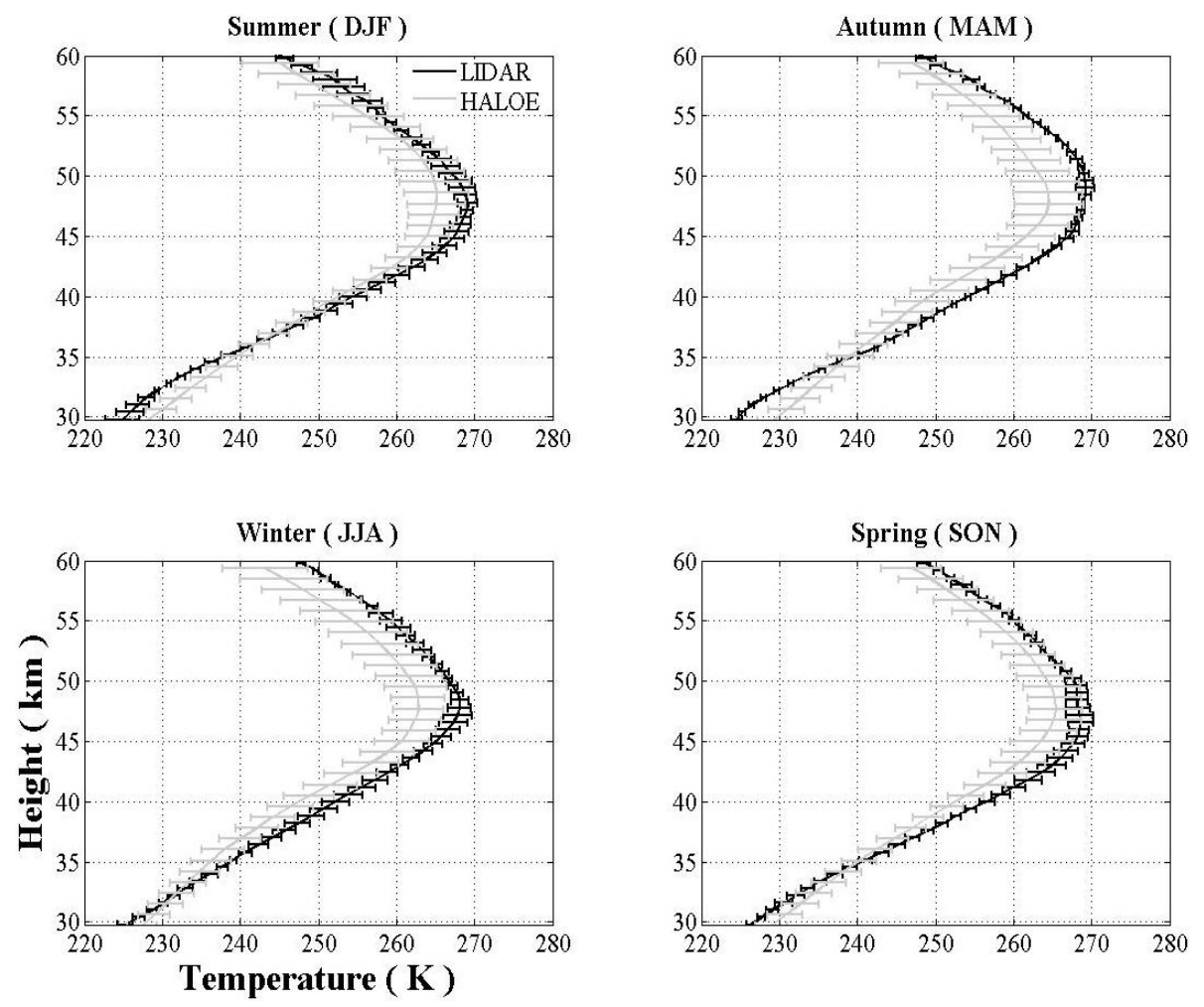

Fig. 6. Height mean seasonal profiles of temperature obtained from the HALOE and LIDAR over Reunion.

gravity and planetary waves. The temperature differences between the LIDAR and HALOE observations are found to be within $\pm 6 \mathrm{~K}$. Such differences are acceptable due to different observational times, sampling volumes (including latitudinal/longitudinal discrepancy in selecting HALOE profile) and vertical resolutions (Sivakumar et al., 2003).

Due to limitations regarding the number of HALOE observations over the LIDAR site, we intend to compare the mean profiles over different austral seasons (summer - DJF, autumn - MAM, winter - JJA and spring - SON). Here, the total number of HALOE observations used for each season corresponds to 44, 59, 64, and 50, respectively. Figure 6 shows the seasonal averaged LIDAR temperature profiles with standard deviation, superimposed by the seasonal averaged HALOE's temperature measurements over Reunion.

At the upper stratosphere height region between $30 \mathrm{~km}$ and $35 \mathrm{~km}$, the LIDAR profiles are found to be systematically lower than the HALOE. The temperature difference is found to be very low during winter in comparison with spring, summer and autumn. The largest difference in temperature is found during the autumn season (MAM).

The HALOE and LIDAR profiles are found to be in fairly good agreement over the stratopause height region $(40 \mathrm{~km}-$ $50 \mathrm{~km}$ ) for summer and spring. The differences between the two are within the limits of the standard deviations of the two profiles.
The lower mesosphere height region $(50 \mathrm{~km}-60 \mathrm{~km})$, the autumn and winter seasonal profiles are apart by a few degrees where the LIDAR shows a higher temperature of about $5 \mathrm{~K}-10 \mathrm{~K}$.

The existence of small differences between LIDAR and HALOE profiles might be related to differences in data sampling, frequency of data used and the observational time differences between HALOE (sunrise and sunset) and LIDAR (night time) including atmospheric tidal disturbances (Raju et al., 2010). Such differences are found to be in agreement with the earlier results reported by Hervig et al. (1996), where they compared the HALOE temperature profiles to that of LIDAR and rocket-sonde and noticed that the measurements typically have random differences less than $5 \mathrm{~K}$ for altitudes below $60 \mathrm{~km}$. A study by Sivakumar et al. (2003) over Northern Hemisphere low latitude stations $\left(13.5^{\circ} \mathrm{N}\right)$ also showed differences in the measurements between LIDAR and HALOE of about $\sim 5 \mathrm{~K}-10 \mathrm{~K}$ in the lower mesospheric height regions. An inter-comparison study by Randel et al. (2004) based on different kinds of middle atmosphere temperature measurements also confirmed that the LIDAR and HALOE are differing within $\pm 5 \mathrm{~K}$. 


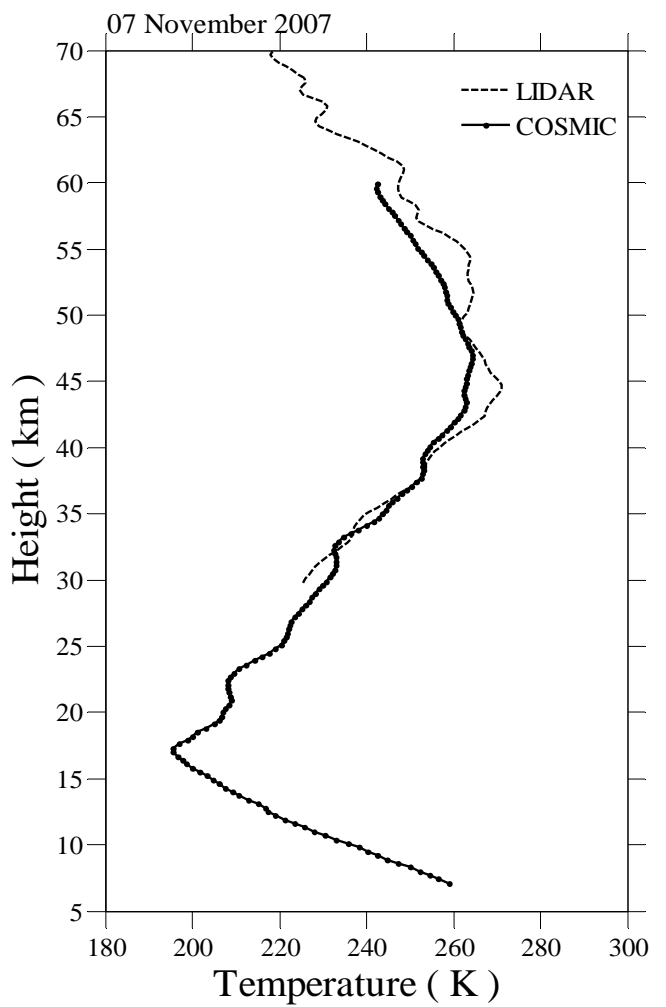

Fig. 7. Height profile of temperature measured by LIDAR and COSMIC over Reunion for 7 November 2007.

\subsection{Comparison between LIDAR and COSMIC satellite data}

In this section, we discuss the comparison between the measured LIDAR and COSMIC temperature profiles. An example of a height profile, recorded on 7 November 2007, is shown in Fig. 7, where the COSMIC temperature profile is derived from $5 \mathrm{~km}$ to $60 \mathrm{~km}$ and the LIDAR profile from $30 \mathrm{~km}$ to $60 \mathrm{~km}$. The COSMIC measurements have lower accuracy for the height region below $5 \mathrm{~km}(\sim 5 \mathrm{~K})$ and sometimes up to $8 \mathrm{~km}(\sim 8 \mathrm{~K})$, which is due to errors associated with the presence of water vapor that causes an incomplete temperature retrieval at these heights. We therefore considered the COSMIC data sets above $5 \mathrm{~km}$ for the present investigation. A small difference in temperature ( \pm 2 to $3 \mathrm{~K}$ ) is noticed in the LIDAR overlap region which may be considered reasonable due to the possible influence of stratospheric aerosols in retrieving temperature from a Rayleigh LIDAR signal (Faduilhe et al., 2005; Gerding et al., 2008). While the general trends between the profiles are similar, the LIDAR profile shows clear wave perturbations in comparison with COSMIC profile (which is found to be smoother). The differences between the LIDAR and COSMIC temperatures are within $\pm 5 \mathrm{~K}$. The COSMIC data considered here, corresponds to the satellite overpass at $20.74^{\circ} \mathrm{S} ; 53.16^{\circ} \mathrm{E}$ which is close to the Reunion LIDAR site $\left(20.8^{\circ} \mathrm{S} ; 55.5^{\circ} \mathrm{E}\right)$. The small difference in temperature may correspond to the actual time of measurements, differences in the techniques employed between the ground and space based systems and different vertical resolution of the data.

Since the COSMIC database is limited to a period of less than 2 years, we intend to compare the monthly mean temperature at different height levels during the period from January 2007 to February 2008. Figure 8a shows the comparison of monthly mean temperatures of COSMIC and LIDAR temperatures at different height levels at an interval of $\sim 3.3 \mathrm{~km}$ in the $30.1-59.8 \mathrm{~km}$ height range, from January 2007 to February 2008. We use collocation criteria between COSMIC and LIDAR data of $\pm 2^{\circ}$ in latitude and $\pm 10^{\circ}$ in longitude. This is regarded as acceptable for coincidences of ground-based and satellite temperature profiles (Kishore et al., 2009). In general, COSMIC and LIDAR monthly averages are matching well. It is expected that the differences and similarities in the COSMIC and LIDAR temperature measurements are due to the LIDAR being a point measurement at a specific location and the considered COSMIC measurements over $\pm 2^{\circ}$ in latitude and $\pm 10^{\circ}$ in longitude. The biases are less in the stratosphere, but they increase with height. The mean bias is less than $3 \mathrm{~K}$ and the standard deviation is $2.4 \mathrm{~K}$. It is also shown that in the stratosphere, there are significant temperature fluctuations which are probably caused by atmospheric waves which produce periodic differences between the GPS/MET and radiosonde profiles (Tsuda et al., 2000).

Further, in order to access the statistical characteristics of middle atmospheric temperatures, we have plotted histograms of the probability distribution function (PDFs) of GPS/COSMIC and LIDAR temperatures for the above presented altitude levels (see Fig. 8b). PDFs are studied for each dataset and this approach makes it possible to evaluate the consistency between data sets without the need for co-location in space and time. The mean temperature and their standard deviations are mentioned in the figure. Both, LIDAR and COSMIC temperature profiles illustrate mostly Gaussian distributions and a very good agreement is found for the heights $33.4 \mathrm{~km}$ and $36.7 \mathrm{~km}$ where the differences are less than $1 \mathrm{~K}$. The mean temperature differences are found to be less at lower stratosphere height regions, increasing with height. The maximum difference in value is found to be $\sim 4 \mathrm{~K}$ at the upper stratosphere height region. In general, the temperature measured by LIDAR is found to be warmer than the one measured by COSMIC. In most cases, the standard deviations for LIDAR are found be higher than for COSMIC.

We have performed regression analysis on measured temperature values between LIDAR and COSMIC at different height regions based on the data from January 2007 to February 2008 . The regression coefficient $\left(R^{2}\right)$ shows a high correlation below the stratopause heights regions and the $R^{2}$ values are decreasing while moving upwards $(65 \%$ at $34 \mathrm{~km}$ and $51 \%$ at $58 \mathrm{~km}$ ) (figures are not shown). 

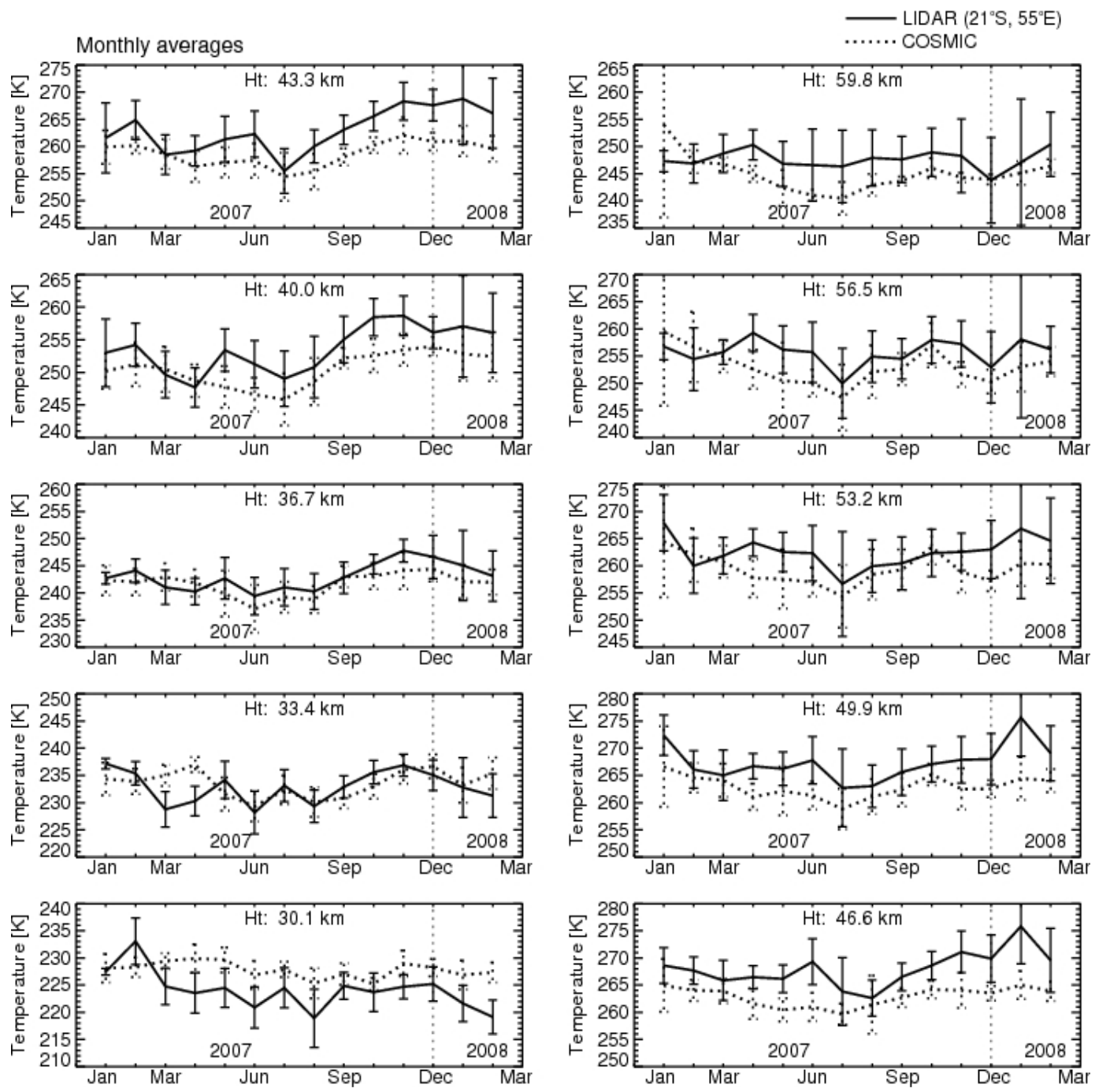

Fig. 8a. Inter-comparison of the monthly mean temperature values at selected heights between LIDAR and COSMIC observations for the year 2007 and 2008.

\subsection{Seasonal oscillations (AO, SAO and QBO)}

As mentioned earlier in Sect. 2, based on the long term and common period of observations (6 years, 2002-2007) from LIDAR, SABER, COSMIC+CHAMP, we have made use of the combined GPS data sets from COSMIC and CHAMP to study the seasonal variations over Reunion $\left(20.8^{\circ} \mathrm{S}, 55.5^{\circ} \mathrm{E}\right)$. Prior to the seasonal analysis, we demonstrate the temporal variations of temperature over Reunion as derived by LIDAR, SABER, COSMIC and CHAMP (hereafter called as CHAMP) experiments. Figure 9 shows the temporal evolution of monthly mean temperatures at different height regions and for the time period from January 2002 to December 2007. The LIDAR monthly mean temperature values are superimposed with the SABER and CHAMP (CHAMP+ COSMIC) monthly mean data. The CHAMP data has been used for earlier years of data. It is evident from the figure that the LIDAR values are in good agreement with SABER and CHAMP values at the lower height region (at $32 \mathrm{~km}$ ). At $40 \mathrm{~km}$, the satellite temperature measurements illustrate similar magnitudes while the LIDAR temperatures are found to $\sim 3-5 \mathrm{~K}$ higher. Higher up, a clear departure in the temperature is evident between LIDAR and the satellite (SABER and CHAMP). In general, the satellite measurements do not differ much while the LIDAR shows $6 \mathrm{~K}$ to $10 \mathrm{~K}$ higher with CHAMP and $10 \mathrm{~K}$ to $16 \mathrm{~K}$ with SABER. LIDAR illustrates a lower temperature at the upper stratosphere height region (below stratopause) and higher temperatures above the stratopause heights. This kind of difference is more visible just above the stratopause height region $(56 \mathrm{~km})$. Such a difference in temperature was also noticed by Cooper (2004) and Dou et al. (2009) when they compared LIDAR and SABER temperature retrievals. They discussed and suggested that such differences might be due to a bias in SABER 


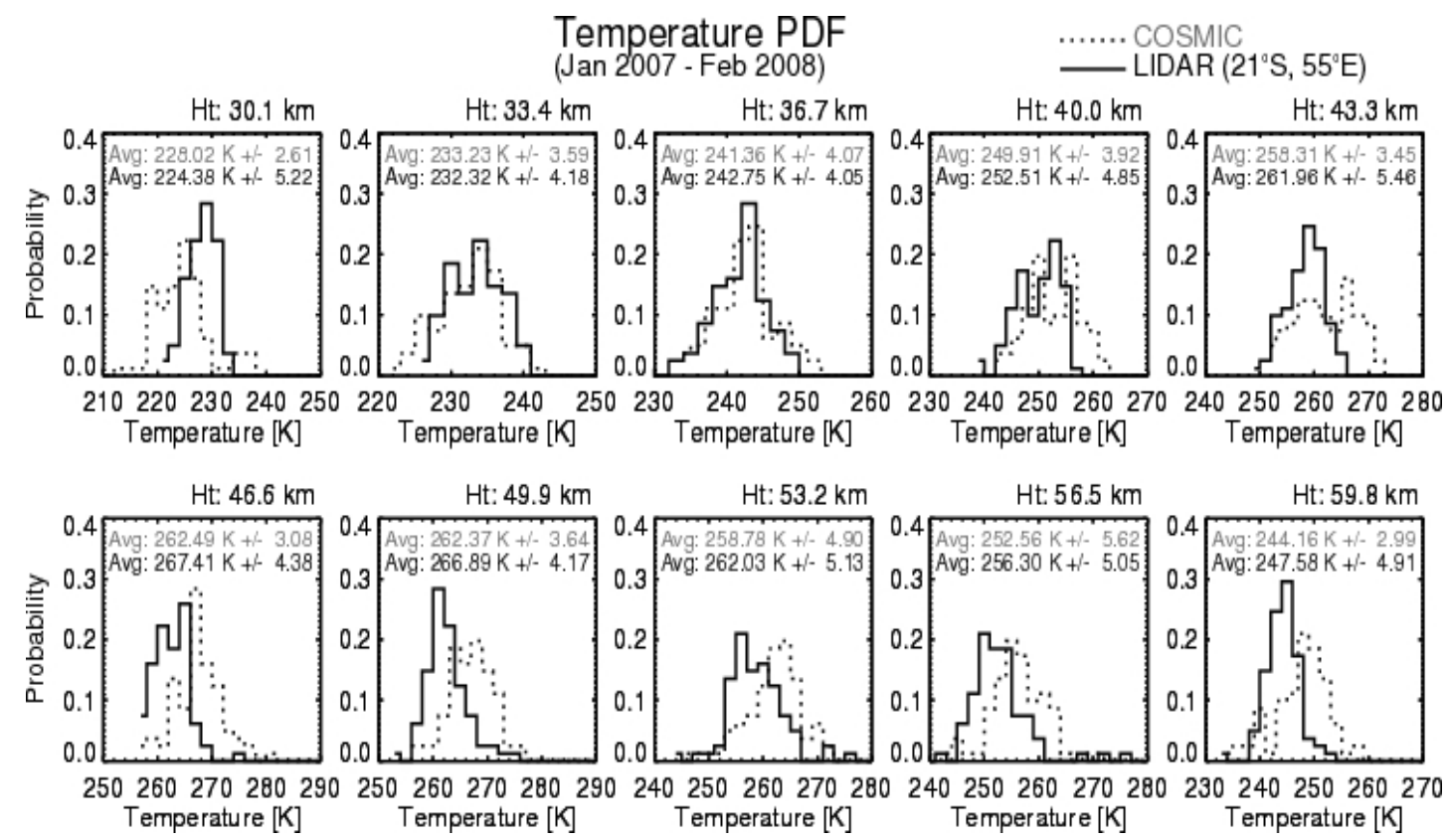

Fig. 8b. The probability distribution function (PDF) obtained between LIDAR and COSMIC temperature values at selected heights.
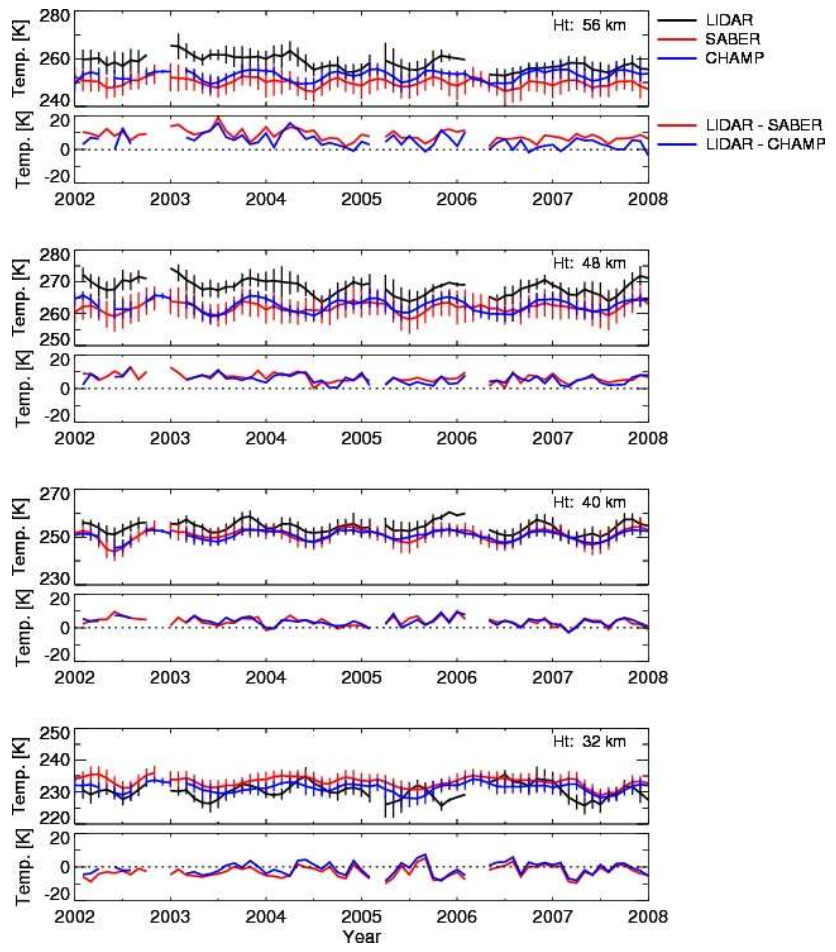

Fig. 9. Temporal evolution of the monthly mean temperature (upper plots) and differences (lower plots) from LIDAR, SABER and GPS (CHAMP plus COSMIC) observations at four different height regions, $32 \mathrm{~km}, 40 \mathrm{~km}, 48 \mathrm{~km}$ and $56 \mathrm{~km}$. temperature. Moreover, atmosphere tide disturbances (Morel et al., 2002; Raju et al., 2010) may partly contribute to such difference. The above long-term temperature measurements are subjected to band-pass filtering and then used to study the seasonal oscillations.

In order to extract $\mathrm{AO}, \mathrm{SAO}$ and $\mathrm{QBO}$ variations, we have applied Lomb-Scargle (L-S) periodogram analysis (Scargle, 1982; Lomb, 1976) and calculated the spectral amplitudes of the different periodicity ( 6 months, 12 months and 23 36 months) from the temperature data. The advantage of this method is that the input data does not need to be evenly spaced (Press et al., 1992). Compared to the other methods, the L-S method weights the data on a per-point basis, instead of per-time basis. Also, L-S periodogram can provide an estimate of the significance of each peak by examining the probability of it arising from a random fluctuation (Luo et al., 2002). The above method has also been used by the authors for studying planetary wave activity (Kishore et al., 2006). The long-term trends in the data are suppressed by applying the second order polynomial fit on the temperature profile prior to spectral analysis. Figure 10 shows the amplitude spectra for the four different height regions 32, 40,48 and $56 \mathrm{~km}$. The horizontal lines in the figure correspond to the $95 \%$ of confidence level. The spectral analysis indicates three dominant peaks that correspond to 6,12 and 28 months periods which correspond to the semi-annual, annual and quasi-biennial atmospheric oscillations, respectively. The SAO amplitudes are the smallest, about half of the AO amplitudes for all the height regions. The QBO spectral peaks are broader than those of seasonal cycles: $\mathrm{AO}$ and $\mathrm{SAO}$. Based on the expected period of oscillations, $\mathrm{AO}$ and 


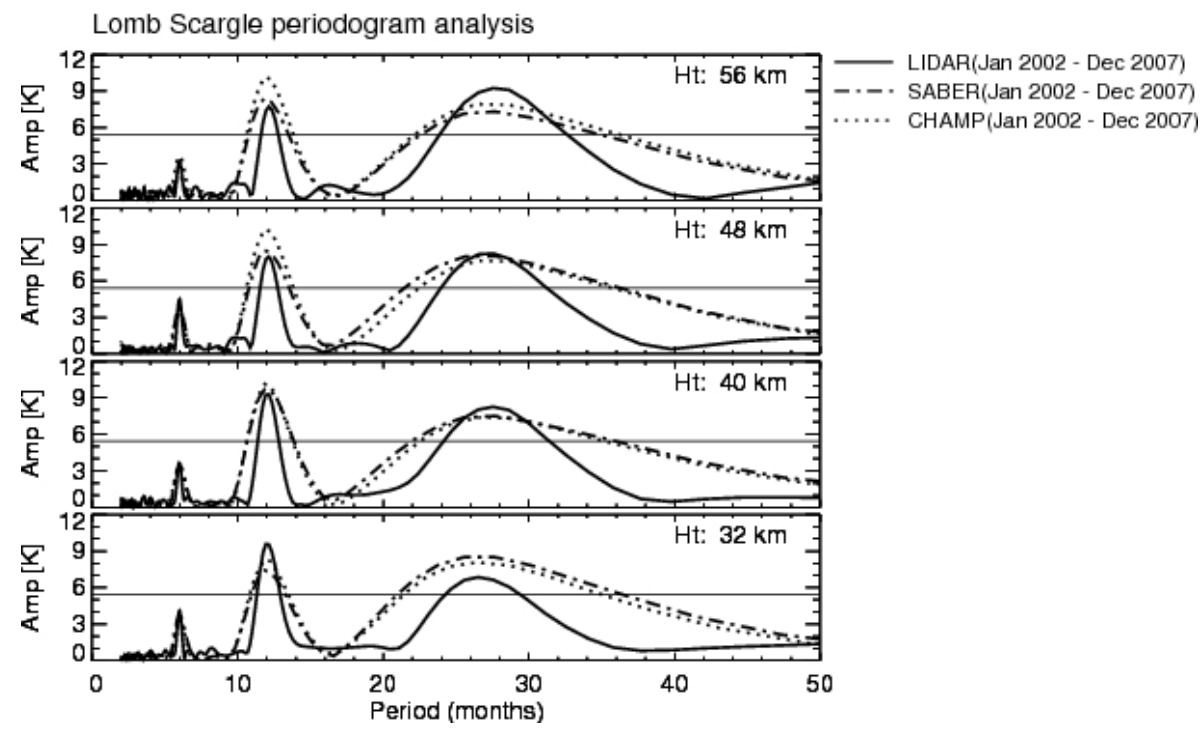

Fig. 10. The spectral amplitudes of the temperature data obtained from LIDAR, SABER and GPS (CHAMP+COSMIC) for the height levels at $32 \mathrm{~km}, 40 \mathrm{~km}, 48 \mathrm{~km}$ and $56 \mathrm{~km}$, based on the same datasets used for Figs. 8 and 9.

SAO are always well defined cycles of 12 and 6 months, whereas the QBO periodicity varies from 22 to 40 months (Pascoe et al., 2005). This might be the reason for the observed broad spectrum. Although a large data base is required to confirm the statement, the obtained broader spectrum may be realistic based on measured confidence level (see horizontal line in Fig. 10). The present results show that the QBO has a periodicity of about 26-28 months. The measured amplitudes for $\mathrm{AO}$ and QBO have higher magnitudes and a broader spectrum than the SAO, which has a lower magnitude and a narrower spectrum. The AO amplitudes are found to be approximately 2 times greater than that of SAO, which is in good agreement with the findings reported by Kawahara et al. (2004). Recent results from Dou et al. (2009) also confirm that the AO is a dominant component in the middle atmospheric thermal variability. While SAO amplitudes are similar for the LIDAR and satellite measurements, a small difference in magnitudes is noticed for AO and QBO. Such differences are also reported by Dou et al. (2009) while comparing with LIDAR and SABER datasets. They outlined that the amplitude differences might arise due to the difference in data sampling between ground and space-based measurements in addition to the tidal oscillation effects. Since the LIDAR data is limited to the night time, determining the tidal oscillations is difficult and may interact with the seasonal cycles (AO and SAO) (Morel et al., 2002; Raju et al., 2010). The maximum amplitudes are almost the same for the height region at $40 \mathrm{~km}$, except the LIDAR has narrower spectra in comparison with GPS and SABER. The SAO amplitudes at different layers are about $3 \mathrm{~K}$. This is in agreement with the results reported by Dou et al. (2009) and Remsberg et al. (2002a) where they found the amplitudes around 2-
$3 \mathrm{~K}$ in the lower and upper stratosphere height region. On the other hand, SABER shows a broader spectrum for all the studied height regions. Interestingly, the LIDAR data shows a decrease in amplitude while moving from $32 \mathrm{~km}$ to $56 \mathrm{~km}$ for $\mathrm{AO}$ and increase in values for QBO. We have further examined the earlier UARS/MLS datasets, collected for the period from 1982 to 1999 over Reunion, and found a clear AO from $38 \mathrm{~km}$ to $48 \mathrm{~km}$ with the highest peak at $45 \mathrm{~km}$ (figures are not shown).

\section{Summary and concluding remarks}

The middle atmosphere thermal structure over a southern sub-tropical site, Reunion $\left(21^{\circ} \mathrm{S} ; 55^{\circ} \mathrm{E}\right)$ is presented for the first time based on 14 years (1994-2007) of Rayleigh LIDAR observations, 11 years (1994-2004) of HALOE, 6 years (2002-2007) of SABER, 6 years (2002-2007) of CHAMP and less than 2 years (January 2007-February 2008) of COSMIC datasets. The obtained LIDAR temperature measurements were compared with different satellite measurements (HALOE, SABER, CHAMP and COSMIC). The major findings of the study are:

- The LIDAR monthly mean temperature shows maximum values from $260 \mathrm{~K}$ to $270 \mathrm{~K}$ at the stratopause height regions from $44 \mathrm{~km}$ to $52 \mathrm{~km}$. While there is no clear signature of seasonal oscillation in the stratopause height, the stratopause temperature shows distinct maxima during the periods March-April and OctoberNovember.

- The comparison between the LIDAR and different satellite measurements are in good agreement and the 
difference is found to be within $\pm 5-6 \mathrm{~K}$. The order of difference is found to be comparable for the most of heights and is higher for upper stratosphere region by SABER. LIDAR illustrates a lower temperature at the upper stratosphere height region (below stratopause) and higher temperature above the stratopause heights. The slight differences noticed between the LIDAR and satellite measurements might be due to the difference in the techniques employed, location and the time of measurements.

- The seasonal variations show a dominant AO in the height region from $30-60 \mathrm{~km}$ and the measured spectral amplitudes are found to be in good agreement with the earlier reported results. The QBO shows increasing amplitudes in the LIDAR data from the lower to upper height regions and the periodicity is found to be $\sim 26-$ 28 months.

Acknowledgements. The present work is supported by the FrenchSouth African co-operative programme and supported by the French Centre National de la Recherche Scientifique (CNRS), the Regional Council, Conseil Regional de La Réunion and the South Africa National Research Foundation (NRF). The study is made in the framework of the European Integrated Project Global Earth Observation and Monitoring of the Atmosphere (GEOMON: contract number FOP6-2005-Global-4-036677), The first author (VSK) acknowledges Universite de la La Réunion for hosting him under invited researcher/professor cadre, and National Research Foundation (South Africa) for travel support through a bi-lateral research project (UID 68668/73449). The authors are thankful for the SABER, HALOE, GPS/CHAMP and COSMIC data centres for the public access via their website.

Topical Editor C. Jacobi thanks P. Batista and another anonymous referee for their help in evaluating this paper.

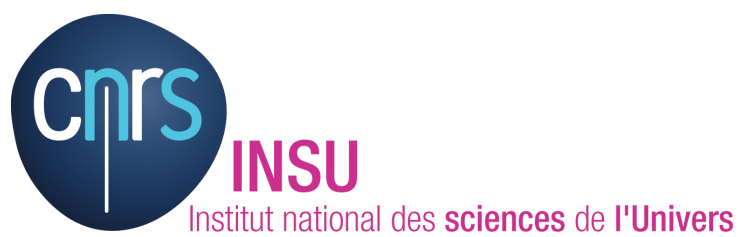

The publication of this article is financed by CNRS-INSU.

\section{References}

Anthes, R. A., Rocken, C., and Kuo, Y. H.: Applications of COSMIC to meteorology and climate, Terr. Atmos. Oceanic Sci., 11, 115-156, 2000.

Anthes, R. A., Ecotr, D., Hunt, D. C., Kuo, Y.-H., Schreiner, W. S., Sokolovskiy, S. V., Syndergaard, S., Wee, T.-K., Zeng, Z., Bernhardt, A., Dymond, K. F., Chen, Y., Liu, H., Manning, K., Randel, W. J., Trenberth, K. E., Cucurull, L., Healy, S. B., Ho, S.-P., McCormick, C., Meehan, T. K., Thompson, D. C., and Yen, N. L.: The COSMIC/FORMOSAT-3 mission: Early results, B. Am. Meteorol. Soc., 89, 313-333, doi:10.1175/BAMS-89-3313, 2008.
Batista, P. P., Clemesha, B. R., and Simonich, D. M.: Tidal associated temperature disturbances observed at the middle atmosphere $(30-65 \mathrm{~km})$ by a Rayleigh LIDAR at $23^{\circ}$, Adv. Space Res., 41(9), 1408-1414, 2008.

Batista, P. P., Clemesha, B. R., and Simonich, D. M.: A 14-year monthly climatology and trend in the $35-65 \mathrm{~km}$ altitude range from Rayleigh LIDAR temperature measurements at a low latitude station, J. Atmos. Solar-Terr. Phys., 71, 1456-1462, 2009.

Bencherif, H., Keckhut, P., Hauchecorne, A., Leveau, J., Megie, G., and Bessafi, M.: Rayleigh-Mie Lidar measurements over Reunion Island : Validation and preliminary results, 18th International Laser Radar Conference, Berlin, Germany, 1996.

Bencherif, H., Moorgawa, A., Morel, B., Michaelis, M., Leavue, J., Hauchecorne, A., Porteneuve, J., and Faduilhe, D.: First validation of stratospheric temperature profiles obtained by a Rayleigh LIDAR over Durban, South Africa, South African Jl. of Sci., 96, $1-6,2000$.

Bencherif, H., Charyulu, D. V., Amraoui, L. E., Peuch, V.-H., Semane, N., and Hauchecorne, A.: Examination of the 2002 major warming in the Southern Hemisphere using ground-based and Odin/SMR assimilated data: stratospheric ozone distribution and tropic/mid-latitude exchange, Can. J. Phys., 85, 1287-1300, 2007.

Chanin, M. L. and Hauchecorne, A.: LIDAR study of the structure and dynamics of the middle atmosphere, Indian J. Radio Space Phys., 20, 1-11, 1991.

Clancy, R. T., Rusch, D. W., and Callan, M. T.: Temperature minima in the average thermal structure of the middle atmosphere (70-80 km) from analysis of 40- to 92-km SME global temperature profiles, J. Geophys. Res., 99, 19001-19020, 1994.

Cooper, M.: Validation of SABER temperature measurements using ground-based instruments, IEEE, 4099-4101, 2004.

Dou, X., Tao, L., Xu, J., Liu, H.-L., Xue, X., Wang, S., Leblanc, T., McDermid, S., Hauchecorne, A., Keeckhut, P., Bencherif, H., Heinselman, C., Steinbrecht, W., Mlynczak, M. G., and Russell III, J. M.: Seasonal oscillations of middle atmosphere temperature observed by Rayleigh LIDARs and their comparisons with TIMED/SABER observations, J. Geophys. Res., 114, D20103, doi:10.1029/2008JD011654, 2009.

Faduilhe, D., Keckhut, P., Bencherif, H., Robert, L., and Baldy, S.: Stratospheric temperature monitoring using a vibrational Raman LIDAR. Part 1: aerosols and ozone interferences, J. Environ. Monit., 7, 357-364. doi:10.1039/b415299a, 2005.

Fishbein, E. F., Cofield, R. E., Froidevaux, L., Jarnot, R. F., Lungu, T., Read, W. G., Shippony, Z., Aters, J. W., McDermi, I. S., McGee, T. J., Singh, U., Gross, U., Hauchecorne, A., Keckhut, P., Gelman, M. E., and Nagatani, R. M.: Validation of UARS Microwave Limb Sounder temperature and pressure measurements, J. Geophys. Res., 101, 9983-10016, 1996.

Gerding, M., Höffner, J., Lautenbach, J., Rauthe, M., and Lübken, F.-J.: Seasonal variation of nocturnal temperatures between 1 and $105 \mathrm{~km}$ altitude at $54^{\circ} \mathrm{N}$ observed by lidar, Atmos. Chem. Phys., 8, 7465-7482, doi:10.5194/acp-8-7465-2008, 2008.

Gille, J. C., Bailey, P. L., Massie, S. T., Lyjak, L. V., Dwards, D. P., Roche, A. E., Kumer, J. B., Mergenthaler, J. L., Gross, M. R., Hauchecorne, A., Keckhut, P., McGee, T. J., McDermid, I. S., Miller, A. J., and Sing, U.: Accuracy and precision of cryogenic limb array etalon spectrometer (CLAES) temperature retrievals, J. Geophys. Res., 101, 9583-9602, 1996. 
Gobbi, G. P., Souprayen, C., Congeduti, F., Di Donfrancesco, G., Adriani, A., Viterbini, M., and Centurioni, S.: Lidar observations of middle atmosphere temperature variability, Ann. Geophys., 13, 648-655, doi:10.1007/s00585-995-0648-0, 1995.

Hajj, G. A., Kursinski, E. R., Romans, L. J., Betiger, W. I., and Leroy, S. S.: A technical description of atmospheric sounding by GPS occultation, J. Atmos. Solar-Terr. Phys., 64, 451-469, 2002.

Hauchecorne, A. and Chanin, M. L.: Density and temperature profiles obtained by LIDAR between 30 and $70 \mathrm{~km}$, Geophys. Res. Lett., 7, 565-568, 1980.

Hauchecorne, A., Chanin, M. L., and Keckhut, P.: Climatology and trends of the middle atmospheric temperature $(33-87 \mathrm{~km})$ as seen by Rayleigh LIDAR over the south of France, J. Geophys. Res., 96, 15297-15309, 1991.

Hervig, M. E., Russell, J. M., Gordley, L. L., Drayson, S. R., Stone, K., Thompson, R. E., Gelman, M. E., McDermid, I. S., Hauchecorne, A., Keckhut, P., McGee, T. J., Singh, U. N., and Gross, M. R.: A validation of temperature measurements from the Halogen Occultation Experiment, J. Geophys. Res., 101, 10277-10286, 1996.

Kawahara, T. D., Gardner, C. S., and Nomura, A.: Observed temperature structure of the atmosphere above Syowa Station, Antarctica $\left(69^{\circ} \mathrm{S}, 39^{\circ} \mathrm{E}\right)$, J. Geophys. Res., 109, D12103, doi:10.1029/2003JD003918, 2004.

Keckhut, P., McDermid, S., Swart, D., McGee, T., GodinBeekmann, S., Adriani, A., Barnes, J., Baray, J.-L., Bencherif, H., Claude H., De Sarra, A., Fiocco, G., Hansen, G., Hauchecorne, A., Lablanc, T., Lee, C. H., Pal, S., Megie, G., Nakane, H., Neuber, R., Steinbrecht, W., and Thayer, J.: Review of ozone and temperature lidar validations performed within the framework of the Network for the Detection of Stratospheric Change, J. Environ. Monit., 6, 721-733, 2004

Kishore, P., Namboothiri, S. P., Igarashi, K., Sivakumar, V., Thulasiraman, S., Subba Reddy, I. V., Mizutani, K., Narayana Rao, D., Rao, S. V. B., and Bhavani Kumar, Y.: Rayleigh LIDAR observations of planetary waves in the middle atmosphere over Gadanki (13.5 ${ }^{\circ}$ N, 79. $2^{\circ}$ E), J. Atmos. Terr. Phys., 68, 901-910, 2006.

Kishore, P., Namboothiri, S. P., Jiang, J. H., Sivakumar, V., and Igarashi, K.: Global temperature estimates in the troposphere and stratosphere: a validation study of COSMIC/FORMOSAT-3 measurements, Atmos. Chem. Phys., 9, 897-908, doi:10.5194/acp-9-897-2009, 2009.

Kursinski, E. R., Hajj, G. A., Hardy, K. R., Schofield, J. T., and Linfield, R.: Observing Earth's atmosphere with radio occultation measurements using the Global Positioning System, J. Geophys. Res., 102, 23429-23465, 1997.

Leblanc, T., Mcdermid, L. S., Hauchecorne, A., and Keehut, P.: Evaluation and optimization of LIDAR temperature analysis algorithms using simulated LIDAR data, J. Geophys. Res., 103, 6177-6187, 1998a.

Leblanc, T., McDermid, L. S., Keckhut, P., Hauchecorne, A., She, C. Y., and Krueger, D. A.: Temperature climatology of the middle atmosphere from long-term LIDAR measurements at middle and low latitudes, J. Geophys. Res., 103, 17191-17204, doi:10.1029/98JD01347, 1998b.

Li, T., Leblanc, T., and McDermid, L. S.: Interannual variations of middle atmospheric temperature as measured by the JPL LIDAR at Mauna Loa Observatory, Hawaii $\left(19.5^{\circ} \mathrm{N}, 155.6^{\circ} \mathrm{W}\right)$, J. Geo- phys. Res., 113, D14109, doi:10.1029/2007JD009764, 2008

Lomb, N. R.: Least-square frequency analysis of unequally spaced data, Astrophys. Space Sci., 39, 447-462, 1976.

Luo, Y., Manson, A. H., Meek, C. E., Meyer, C. K., Burrage, M. D., Fritts, D. C., Hall, C. M., Hocking, W. K., MacDougall, J., Riggin, D. M., and Vincent, R. A.: The 16-day planetary waves: multi-MF radar observations from the arctic to equator and comparisons with the HRDI measurements and the GSWM modelling results, Ann. Geophys., 20, 691-709, doi:10.5194/angeo20-691-2002, 2002.

Mbatha, N., Sivakumar, V., Malinga, S. B., Bencherif, H., and Pillay, S. R.: Study on the impact of sudden stratosphere warming in the upper mesosphere-lower thermosphere regions using satellite and HF radar measurements, Atmos. Chem. Phys., 10, 3397-3404, doi:10.5194/acp-10-3397-2010, 2010.

Melbourne, W. G., Davis, E. S., Duncan, C. B., Hajj, G. A., Hardy, K. R., Kursinski, E. R., Meehan, T. K., Young, L. E., and Yunck, T. P.: The application fos space borne GPS to atmospheric limb sounding and global change monitoring, Jet Propulsion Laboratory Rep., 94(18), 147 pp., 1994.

Moorgawa, A., Bencherif, H., Michaelis, M. M., Porteneuve, J., and Malinga, S.: The Durban atmospheric LIDAR, Optics \& Laser Tech, 39, 306-312, 2007.

Morel, B., Bencherif, H., Keckhut, P., Baldy, S., and Hauchecorne, A.: Evidence of tidal perturbations in the middle atmosphere over Southern Tropics as deduced from LIDAR data analysis, J. Atmos. Solar Terr. Phys., 64, 1979-1988, 2002.

Pascoe, C. L., Gray, L. J., Crooks, S. A., Juckes, M. N., and Baldwin, M. P.: The quasi-biennial oscillation: Analysis using ERA-40 data, J. Geophys. Res., 110, D08105, doi:10.1029/2004JD004941, 2005.

Portman, R. W., Thomas, G. E., Solomon, S., and Garcia, R. R.: The importance of dynamical feedbacks on doubled $\mathrm{CO}_{2}$-induced changed in the thermal structure of the mesosphere, Geophys. Res. Lett., 22, 1733-1736, 1995.

Press, W. H., Teukolsky, S. A., Vetterling, W. T., and Flannery, B. P.: Numerical Recipes in C: The Art of Scientific Computing, 2nd ed., Cambridge University Press, Cambridge, 994 p., 1992.

Raju, U. J. P., Keckhut, P., Courcoux, Y., Marchand, M., Bekki, S., Morel, B., Bencherif, H., and Hauchecorne, A.: Nocturnal temperature changes over tropics during CAWSES-III campaign: Comparison with numerical models and satellite data, J. Atmos. Solar Terr. Phys., 72, 1171-1179, 2010.

Randel, W. J., Wu, F., Russell III, J. M., Roche, A., and Waters, J. W.: Seasonal cycles and QBO variations in stratosphere $\mathrm{CH}_{4}$ and $\mathrm{H}_{2} \mathrm{O}$ observed in UARS HALOE data, J. Atmos. Sci., 55, 163-185, 1998.

Randel, W., Udelhofen, P., Fleming, E., Geller, M., Gelman, M., Hamilton, K., Karoly, D., Ortland, D., Pawson, S., Swinbank, S., Wu, F., Baldwin, M., Chanin, M. L., Keckhut, P., Labizke, K., Remsber, E., Simmons, A., and Wu, D.: The SPARC Intercomparison of Middle-Atmosphere Climatologies, J. Climate, 17, 986-1003, 2004.

Rauthe, M., Gerding, M., and Lübken, F.-J.: Seasonal changes in gravity wave activity measured by lidars at mid-latitudes, Atmos. Chem. Phys., 8, 6775-6787, doi:10.5194/acp-8-6775-2008, 2008.

Remsberg, E.: On the verification of the quality of SABER temperature, geopotential height, and wind fields by comparison with 
Met Office assimilated analyses, J. Geophys. Res, 108(D19), 4628, doi:1029/2003JD003720, 2003.

Remsberg, E., Bhatt, P. B., and Deaver, L. E.: Seasonal and longer-term variations in middle atmosphere temperature from HALOE on UARS, J. Geophys. Res., 107(D19), 4411, doi:10.1029/2001JD001366, 2002a.

Remsberg, E., Deaver, L., Wells, J., Lingenfelser, G., Bhatt, P., Gordley, L., Thompson, R., McHugh, M., Russell, J. M., Keckhut, P., and Schmidlin, F.: An assessment of the quality of Halogen Occultation Experiment temperature profiles in the mesosphere based on comparisons with Rayleigh backscatter LIDAR and inflatable falling sphere measurements, J. Geophys. Res., 107(D20), 4447, doi:10.1029/2001JD001521, 2002b.

Roble, R. G. and Dickinson, R. E.: How will changes in carbon dioxide and methane modify the mean structure of the mesosphere and thermosphere?, Geophys. Res. Lett., 16(12), 14411444, doi:10.1029/GL016i012p01441, 1989.

Russell III, J. M., Gordley, L. L., Park, J. H., Drayson, S. R., Hesketh, W. D., Cicerone, R. J., Tuck, A. F., Frederick, J. E., Harries, J. E., and Crutzen, P. J.: The Halogen Occultation Experiment, J. Geophys. Res., 98, 10777-10797, 1993.

Scargle, J. D.: Studies in astronomical time series analysis, II, statistical aspects of spectral analysis of unevenly spaced data, Astrophys. J., 263, 835-853, 1982.

Schöch, A., Baumgarten, G., and Fiedler, J.: Polar middle atmosphere temperature climatology from Rayleigh lidar measurements at ALOMAR (69 $\mathrm{N})$, Ann. Geophys., 26, 1681-1698, doi:10.5194/angeo-26-1681-2008, 2008.

Schreiner, W., Rocken, C., Sokolovskiy, S., Syndergaard, S., and Hunt, D.: Estimates of the precision of GPS radio occultations from the COSMIC/FORMOSAT-3 mission, Geophys. Res. Lett., 34, L04808, doi:10.1029/2006GL027557, 2007.

Sivakumar, V., Rao, P. B., and Krishnaiah, M.: LIDAR measurements of stratosphere-mesosphere thermal structure at a low latitude: Comparison with satellite data and models, J. Geophys. Res., 108(D11), 4342, doi:10.1029/2002JD003029, 2003.
Sivakumar, V., Morel, B., Bencherif, H., Baray, J. L., Baldy, S., Hauchecorne, A., and Rao, P. B.: Rayleigh lidar observation of a warm stratopause over a tropical site, Gadanki $\left(13.5^{\circ} \mathrm{N}\right.$; 79. ${ }^{\circ}$ E), Atmos. Chem. Phys., 4, 1989-1996, doi:10.5194/acp4-1989-2004, 2004.

Sivakumar, V., Bencherif, H., Hauchecorne, A., Keckhut, P., Rao, D. N., Sharma, S., Chandra, H., Jayaraman, A., and Rao, P. B.: Rayleigh lidar observations of double stratopause structure over three different northern hemisphere stations, Atmos. Chem. Phys. Discuss., 6, 6933-6956, doi:10.5194/acpd-6-6933-2006, 2006.

Sokolovskiy, S. V., Rocken, C., Lenschow, D. H., Kuo, Y. H., Anthes, R. A., Schreiner, W. S., and Hunt, D. C.: Observing the moist troposphere with radio occultation signals from COSMIC, Geophys. Res. Lett., 34, L18802, doi:10.1029/2007GL030458, 2007.

Steiner, A. K. and Kirchengast, G.: Gravity wave spectra from GPS/MET occultation observations, J. Atmos. Oceanic Tech., 17, 495-503, 2000.

Tsuda, T., Nishida, M., Rocken, C., and Ware, H.: A global morphology of gravity wave activity in the stratosphere revealed by the GPS occultation data (GPS/MET), J. Geophys. Res. 105(D6), 7257-7273, 2000.

Whiteway, J. A. and Carswell, A. I.: Rayleigh LIDAR observations of thermal structure and gravity wave activity in the high Arctic during a stratospheric warming, J. Atmos. Sci., 51, 3122-3136, 1994.

Wickert, J., Reigber, C., Beyerle, G., Konig, R., Marquardt, C., Schmidt T., Grunwaldt, L., Galas, R., Meehan, T. K., Melbourne, W. G., and Hocke, K.: Atmosphere sounding by GPS radio occultation: First results from CHAMP, Geophys. Res. Lett., 28, 3263-3266, 2001. 